in the Literature department or how choices may have been influenced by their relationship to their mothers, they yield the interests and failings of the confessional autobiography. We are interested in them if we are interested in the narrator. They offer little as a strategy for literary feminism. The contributors are successful professors, but only two acknowledge the status, the power structures, from which they speak. This collection contains the reminiscences of those who have made it into the mainstream. The writers who often transformed our ways of discussing texts, here tell how they arrived at those earlier positions: Nancy Miller and Ann Rosalind Jones on feminist poststructuralism; Barbara Christian and Gloria T. Hull on Black writing; Bonnie Zimmerman on lesbian writing. On historical grounds, the essays are important but can such a discourse be open to their students or to the disempowered? 'Writing about yourself does not liberate you, it just shows how ingrained the ideology of freedom through self-expression is in our thinking' (p. 139) argues Linda S. Kauffmann.

One of the real strengths of this collection is that the editors have not convinced all of the contributors that 'going personal' is useful, so what we get is a complex ongoing debate. Arguments passionately for it come from the majority, including Nancy
Miller, Gloria T. Hull, Ann Rosalind Jones and Bonnie Zimmerman; arguments against the strategy, from Linda S. Kauffman and (in defence of theory) Jerry Aline Fliege. In between, a whole medley of positions exist. Rachel Blau DuPlessis gives us a thoughtful meditation on the problematics of the strategy while Barbara Christian ignores the debate and simply discusses three books by Afro-American women writers that she found influential.

As a collection of essays telling their own history in the institutionalizing of feminist criticism, this book is interesting. As an attempt to shift academic criticism away from theory and back towards empathy and paradigms of success, it is naive and turns its back on all the things that theory has highlighted: suspicion of the constructed unity of the narrative ' $I$ ', the dangers of relying on authenticity and sincerity as measures of value, the lurking imperialism beneath the stance of empathy and author as exemplar. But then, many of the most damning arguments against going personal come from within its own covers. If life is a swamp, Molly Hite suggests, 'it doesn't help all that much to plot routes because ... it doesn't stop being a swamp, you don't arrive at a culminating region of sure footing' (p. 128).

\section{Merja Makinen}

\section{Romancing the Postmodern}

Diane Elam

Routledge: London and New York 1992, ISBN $041507987 \mathrm{X}, £ 10.99 \mathrm{Pbk}$, ISBN 0415057329 , £35.00 Hbk

\section{Comedy: The Mastery of Discourse}

Susan Purdie

Harvester Wheatsheaf: Hertfordshire 1993, ISBN 0 74500724 4, £9.95 Pbk

\section{The Adulteress's Child: Authorship and Desire in the Nineteenth-Century Novel \\ Naomi Segal \\ Polity Press: Oxford 1992, ISBN 0745605095 , £39.50 Hbk}

How many women does it take to change a light bulb? The joke pattern identifies the $x$ after 'how many?' as improper performers or inept 
speakers, which both gives transgressive pleasure, and confirms the teller and the audience, in Susan Purdie's analysis, in superior competence. The topics of the books under review could be defined as light in other senses: the nineteenthcentury fictional adulteress is 'a light woman' whose child fits uneasily into paternal genealogies; definitions of romance, often regarded as light reading, flicker so much that Diane Elam doesn't come down one way or the other on its being properly a 'feminine' form; and while the romance plot as the exchange of women is authoritatively defined as 'the most usual basis of comedy', Purdie (who cites Northrop Frye on this) demotes such literary definitions of comedy as a genre, placing it in a broader and more basic linguistic account of joking and funniness, including ordinary social exchange and TV comedy along with classic drama. All of them are thinking seriously and provocatively about feminist theory and possibilities for resistant practice: their titles put the light term first, the heavy second. Well, Diane Elam starts a correspondence between lightweights, romance and the postmodern, but I think this is related to Luce Irigaray's 'flirting with the philosophers', or in this case having a fling with historians, realists, modernists.

All offer understandings of genres, plots and patterns, and suggest ways out. Purdie and Segal work out from authoritative structures, Elam evades obvious binaries. Her postmodernism is not a name for contemporary art movements (though she starts her thinking with an excellent discussion of Umberto Eco's The Name of the Rose, and ends with Jacques Derrida and Kathy Acker). It is linked to transgressing historical periodicity as a way of thinking about history and representation without claiming final understanding, which therefore is trying to think historically, to understand history in a time (not only the present) when there is 'a loss of credulity in master narratives'. Suggesting that feminism can be other than a modernist movement locating freedom in identity and property, that postmodernism could be the name feminism can give to its escape from identity politics', she tries to match it with the constantly redefined and uncertain genre of romance which, according to Henry James, deals with 'experience ... liberated from the conditions that we usually know to attach to it'. There are anachronistic chapters on Walter Scott, Joseph Conrad and George Eliot, which are not so much new readings of these writers on the borders of historical romance and realism, as ways of seeing how the intersection of gender and genre can make us reconsider what history means, how 'the cultural voice of the colonized is heard within the tropes of romance', how 'the representational framework of political judgement is opened to the play of desires which, emanating as they do from the excluded (women, lost tribes), are a priori irrepresentable'.

It's hard to summarize the arguments of any of these books; summary closes down on their enquiringness. Momentary summaries Elam herself offers are that knowledge will not put an end to desire, nor desire to knowledge; or, '[Barbara] Cartland offers women history as an escape from their own lives, Eco offers readers history as an escape from women'. Distinctions are finely made, between nostalgic and postmodern romance (not the past we have lost, but a threat to presently authorized representations), and between ironic temporality' (the inevitable noncorrespondence between the past and our writing of it) and ironic attitudes deliberately adopted. The latter discussion takes the form of one of Scott's antiquarian footnotes upended into the vertical pagedivision used by Derrida and 
Kristéva. Certainly this book made me more intelligently aware of the pun on 'post' as both 'coming after' and the yearning for impossible correspondence.

While Elam's argument is infolded, implicated, in her way of writing, Purdie's analysis of the structure of joking and its effects is in some danger of repeating the masterful structures (analysed by the linked hands of Saussure, LéviStrauss and Lacan) whose effects she both enjoys and wants to resist; however, we need to explore the layout of the prison if we want to effect an escape. She presents comedy, on Lévi-Strauss's model of communication, as a discourse in which actions form (as well as perform and replicate) significance, including the identities of individuals and groups as subjective agents. Through basic patterns of exchange jokingly misnegotiated (as in courtship, or, rather more in twentiethcentury comedies, postmarital relations) she considers both an arguably universal linguistic or discursive structure, and local problems changing over time, or contemporaneously different, as when, in English jokes at least, the Irish and women are not interchangeable targets (she says 'butts'); the Irishman figuring as inept, the woman as the improper subject, who if she speaks shouldn't. She notes that womandriver jokes are the exception that prove the rule, in not invoking sexuality or male potency, not overtly. When the butt of a joke is a man who can't keep a woman in order, male potency is still endorsed.

Purdie writes interestingly about comedy as discursive, not metaphysical like tragedy (always more class than comedy, as Angela Carter said in Wise Children), and about distinctions between comedy and farce, irony, satire, carnival, as well as literary accounts of comedy which do turn it metaphysical - for example, comedy as reconciliation between unequals ('who is it that is reconciled, and to what?' she asks, knowing how grumpy that can sound), or comedy as celebration of fertility, which is not the same as potency for women, as she rightly says: "there is a difference between establishing that comedy ends with celebratory feelings and agreeing that it should be only and unreflectively celebrated.'

She also queries Regina Barreca's attractive claims about women's comedic writing (Last Laugh, New York, 1988). Without the boundary between the imaginary and the symbolic there would be no transgression, no jokes (Cixous and Irigaray are implicated here) though Purdie does consider an oppositional form of comedy, exemplified through Caryl Churchill, which could not be restricted to 'the feminine'. Her argument (I have focused on its later parts) could be seen as a question about how structural women's funniness or 'lack of humour' is, how far down it goes. One of her minor points it that the clitoris is absent from popular joking (and lesbian sexuality figures only as the absence of masculine penetration). One quibble I would make is that the knowledge called for is sometimes too local, though there is a postscript on 'Cultural relativity and joking structures': you would have to be English TV watchers of a certain generation to know that 'Mainwaring' refers to Dad's Army and 'Margot's neighbours' to The Good Life. Bobby Baker figures on the cover and in a footnote, but though her performances and the work of other feminist artists is said to be 'not always inaccessible', the scholarly apparatus gives us no way of accessing them. These restrictions are possibly the responsibility of the publisher rather than the writer: it is striking that one of these books is available in hard- and paperback in two countries, the others in Britain, one in hardback only, one in paperback only (apparently). I see no good reason for these distinctions. 
All of them negotiate between feminism and the literary or rhetorical which is foregrounded in postmodern and poststructuralist theory. Although Naomi Segal is the closest to traditional literary 'readings' in the body of her book (of French 'récits', and novels by Stendhal, Flaubert, Maupassant, Tolstoy, Hawthorne and Fontane; her dislike of Flaubert and of The Scarlet Letter, 'surely one of the most unpleasant books ever written', is emphatic), she is also the most inclined to make too much of an opposition between empirical feminism and theory, between the reasonable daylight of maternal knowledge and culture's haunting by male phantasy (like Teresa Brennan's The Interpretation of the Flesh, Routledge 1992, according to Rachel Bowlby's response in Women: a Cultural Review, 4, 1 (Spring) 1993:112-17). I was impressed some years ago when I heard her speak of the story of Naomi and Ruth in contrast to that of Sarah and Hagar (strangers bonding with or exiling each other), and how feminists writing about mothers and daughters tended to cast the mother as a daughter to be re-educated; what I've waited for is now available in her introduction. (Purdie's acknowledgement of her son, for 'jokes lady lecturers might not otherwise encounter', confirms the tendency to such dedications, which Segal also notes and exemplifies).

I find Segal's division between patri- and matrilineal texts suggestive, and her consideration of how the phantasy of authorship places characters and readers in motivated desire: 'récits' and realist novels are Oedipal, accounts of the son and the father. We could think also about 'narrating mothers', the narrative of the daughter or much more rarely the mother: the impropriety of being a mother and sexually desirous is one of Segal's concerns, as in E. Anne Kaplan's Representing Motherhood, though the approach and material are very different. In the texts Segal considers, the adulteress is made to encounter her judgement in the sickness of her son, or having a daughter (Segal briefly expands into twentieth-century plays, films and fiction; Max Ophüls's 1949 film melodrama Letter From an Unknown Woman, based on a story by Stefan Zweig, with Joan Fontaine as a heroine who had already starred as Rebecca and Jane Eyre, should be added to her genealogy of the sick son story). As she points out, it is now the adulterous father who is more commonly faced with the choice between love and children; his solution is not generally Anna Karenina's.

However, I found the introduction and conclusion more fascinating than the 'readings', however careful and subtle. It's in the conclusion that earlier metaphors of authorship are explained (flying, hovering, leaning down over). Readings have to follow texts, deferring to them even in exposing their misogyny, but at the end Segal commands an eccentric range of material in the service of her enquiry, setting Baudelaire next to sociobiological evidence (exposing the assumptions built into the language), including Ai No Corrida and questionnaires and interviews with mothers about the anticipated gender of their children. What is her inquiry? It's into the knowledge of mothers, their authority and freedom to choose, and motivated by a passion to remake heterosexual and parental love. I often had to think twice, not always landing where she did. All these books are a provocation to think. Our present, as we make it, is the coming past of our future; not a light thought at all.

Elaine Jordan 